Biomed.

OIL

150

EI3f

1893

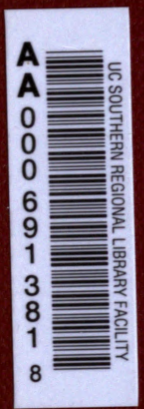




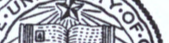

बत.

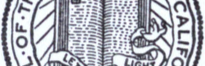

(..)

(1)

THE LIBRARY

OF

THE UNIVERSITY OF CALIFORNIA LOS ANGELES 





$$
\text { . . A . . }
$$

\section{Popular Flora}

DENVER, COLORADO,

\section{ALICE, EAṠTWOOD.}

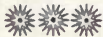

SAN FRANCISCO:

Zoe Publishing Company,

$$
\text { P. O. Box } 2114 .
$$





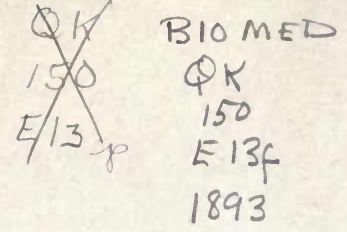

\section{PREF ACE.}

This Flora was written with the sole aim of helping students to learn the names of the plants that grow around Denver. It has been made as simple as possible, and those characteristics only have been noted which seemed to separate any given species from allied forms. The localities are cited generally with exsctness, so as to insure certainty. The accent marks will tell all that is needed about the pronuncation; for with the accent correct it makes but little difference whether the English or continental pronunciation be used. For analytical keys and deseriptions of orders and genera the student will have to consult a more complete manual; either "Coulter's Rocky Mountain Botany" or some one of Gray's text-books.

Establishing the identity of a plant is the first step towards knowing it, though generally it becomes also the last. There should follow observations of its habits and environment; the noting of the insect visitors, their actions and results; comparison with other plants of the same species and with those of allied species to discover variation and detect relationships that may be unsuspected. This is a vast field of original work that has been so neglected that we are forced to almit that we know very little beyond the name of a plant. It is hoped that by facilitating that labor more time can be spared for the intimate acquaintance with the plants.

No descriptions have been attempted in the more difficult orders because they could not be made simple enough for beginners. 'The names will serve as a check list to those who know the species.

As this list probably does not contain the names of all the plants growing around Denver, and as new plants are continually being introduced, any. one who finds a plant that seems to be unrecorded will do a great favor by sending me a specimen in flower and fruit.

"Gray's Manual" has been followed in regard to accentuation and nomenclature. I wish to acknowledge the kindness of Professor Crandall, of the State Agricultural College of Colorado, for the verification of the grasses.

Alice EAstwood.

Academy of Sciences, San Franciscn, Cal. 



\section{FLoRA OF DENVER.}

\section{RANUNCULÁCEæ. (Crowfoot Family.)}

1. Clématis ligústicifolia Nutr. (VIraiv's Bower.) Climbing, diœcious, flowers white, akenes numerous, with feathery tails. Common along Cherry Creek and the Platte,on the plains in North Denver and in Perrin's Meadow. Summer and fall.

2. Anemóne dichótoma L. (Wind-Flower, Anemone.) Flowers large and white. Head of round carpels, globular. Along the Platte and Cherry Creek in damp, shady places. Summer.

3. Thalíctrum Cornúti L. (Meadow-Rue.) Reported by Miss E. Eaton from Clear Creek near Berkeley.

4. Myosúrus minimus L. (Mousetail.) Flowers inconspicuous, spike of akenes elongating and slender. Near Montclair and in North Denver. Spring.

5. Ranúnculus aquátilis L. (White WAter-Crowfoot.) Growing in ponds and streams with finely dissected leaves all under water. There are two varieties, one having the leaves rigid when withdrawn from the water and the other with leaves that collapse. Along Cherry Creek and the Platte. Spring to fall.

6. Ranúnculus Cymbalária Pursh. (STrawberry CrowFоoт.) Flowers small and yellow, stems sending out runners. Common along the ditches and ponds. Spring to autumn.

7. Ranúnculus scelerátus L. (Cursed Crowfoot.) Stems hollow and smooth, flowers small and yellow, akenes numer-

(3) 
ous and falling off readily when ripe. Growing in and near water, along the ditches, etc. Spring to autumn.

8. Ranúnculus Pennsylvánicus L. (Pennsylvanian Crowfoot.) Bristly-hairy, yellow petals smaller than sepals, akenes in oblong heads. Growing near water, summer.

9. Ranúnculus multifidus Pursh. Stems floating, petals yellow. This has been found along Clear Creek near Berkeley by Miss E. Eaton.

хо. Delphinium azúreum Michx. (White Larkspur.) Palmately dissected leaves mostly at base of stem, flowers white with ascending spurs. Common on the plains in early summer.

II. Delphinium bicolor Nutt. (Blue Larkspur.) Flowers deep blue, roots clustered, small and fleshy and too readily separating from the stem. Rare along Cherry Creek. Spring.

12. Delphinium scopulórum Gray. Tall, large blue flowers numerous. Found by Miss E. Eaton near Berkeley, on Clear Creek. Rare near Denver.

\section{PAPAVERÁCEæ̇. (Poppy Family.)}

I3. Argemóne platýceras Link \& OtTo. (MexicAN Poppy.) Flowers large and white, glaucous leaves smooth, except for the prickles, and distinctly white veined. Common on the plains. Summer and autumn.

14. Argemóne hispida Gray. (Bristly Poppy.) Very bristly and hairy, leaves light green but not white-veined. More compact than the preceding and less common. Near Petersburg and Valverde on the plains. Summer.

\section{FUMARIACEE. (Fumitory Family.)}

15. Corýdalis aúrea WILLD. var. occidentalis Gray. (Golden CoRydal.) Racemes of odd-shaped, spurred, yellow 
flowers, herbage smooth and glaucous, stems hollow, seeds shining and black. Common along the North Denver and Valverde hillsides above the Platte, Cherry Creek. Spring, summer.

\section{CRUCÍFERA. (Mustard Family.)}

16. Árabis hirsúta Scop. (HaIry Rock-Cress.) Biennial, flowers inconspicuous, wingless seeds in one row in each cell of the ascending pods. Along the Platte. Spring, summer.

17. Árabis perfoliáta LAM. Biennial,stem leavesglaucous and clasping by the sagittate base, pods erect with two rows of seeds in each cell. Along the Platte. Summer.

18. Árabis Holbóllii Hornem. Perennial, flowers larger, pods spreading downwards with two rows of seeds in each cell Along the Platte. Spring and summer.

19. Drába cuneifolia Nutr. (Whitlow Grass.) Low with stellate pubescence and small white flowers in racemes. Rare around Denver; on the plains in early spring.

20. Camélina satíva Crantz. (False Flax.) An introduced annual with small yellow flowers and numerous pearshaped margined pods. Rare. Valverde, University Park.

2x. Nastúrtium officinále R. Br. (Water Cress.) The common water-cress found growing in the springs near the Platte and Cherry Creek. Introduced.

22. Nastúrtium palústre DC. (Marsi Cress.) Annual, erect, short pods tipped with a short style, leaves pinnately cleft and divisions cut toothed. There is also a low spreading form in fields. In wet places.

23. Erýsimum ásperum DC. (Western W Flowers yellow in racemes, fragrant, pods long, four-sided, spreading horizontally. North Denver and Valverde hills. spring and summer. 
24. Sisýmbrium canéscens NutT. (TANsy-MustaRd.) Yellow flowers very small, pods in elongated racemes shorter than their pedicels. Seeds in two rows in each cell. Spring. Common.

25. Sisýmbrium incísum ExGELM. Seeds in one row, pods usually longer than the spreading pedicels. Clear Creek. Found by Miss E. Eaton.

26. Sisýmbrium officinále Scop. (Hedge-Mustard.) Introduced along the Platte. Rare.

27. Brássica niǵra Косн. (BLAck-MustaRd.) Introduced.

28. Brássica campéstris L. (Turnip.) Introduced.

29. Capsélla Bursa-pastóris Moench. (Shepherd's Purse.) Introduced. Common.

30. Lepídium campéstre $B R$. Introduced. One plant found at Valverde. Summer.

31. Lepidium intermédium Gray. (Pepper-Grass.) Flowers inconspicuous, petals wanting or very small; round, flat emarginate pods numerous in racemes. Common on the plains in early summer.

32. Lesquerella Ludoviciana DC. (Bladder-Pod.) This is the Vesicaria Ludoviciana DC. of Coulter's Manual. Branching from the base, stellately pubescent. Flowers yellow and pods obovate, globose. On the plains. Common in Cherry

- Creek bottom near Broadway Bridge. Spring and summer.

33. Physária didymocárpa Gray. ('Twin-Pod.) Canescent, low and prostrate with many stems bearing numerous yellow flowers and large 2-celled inflated pods. Along the Platte at Valverde. Spring and summer.

34. Ráphanus sativius $\mathrm{L}$. The common radish introduced and running wild. 


\section{CAPPARIDÁCEA. (Caper Family.)}

35. Polanísia trachyspérma T. \& G. (SkUnK-WeEd.) Glandular flowers white with purple filaments, odor disagreeable, pods upright. Platte bottom in sandy places. Summer.

36. Cleóme integrifólia T. \& G. (Bee Plant, RattleeWeED.) Tall and branching, flowers reddish-purple or rarely white, pods numerous, flattened, an inch or two long, hanging. Common. Summer and fall.

\section{VIOLÁCEÆE. (Violet Family.)}

37. Vióla cuculláta Ait. (Blue Violet.) Round kidneyshaped leaves from a short root-stock. In damp places along the Platte and Cherry Creek. Spring.

38. Víla delphinifólia Nuttr. (Lakkspur-Leaved Violet.) Flowers blue, leaves 5 to 7 -parted, divisions cleft into linear lobes. Clear Creek near Berkeley.

39. Víola Canadénsis L. (CAnadian Violet.) Flowers white and pink, stem sometimes branching diffusely. Rare along the Platte near Overland Park. Spring.

40. Víla Nuttállii Pursh. (Yellow Violet, JohnnyJump-Up.) Leaves lance-shaped. On the plains in early spring.

\section{CARYOPHYLLÁCEÆE. (Pink Family.)}

4r. Siléne antirrhína L. (Sleepy Catch-Fly.) Annual with viscid joints, petals small and pink, flowers opening for a short time in sunshine. Capsules large. Rare along the Platte.

42. Lýchnis Drummóndii Watson. Rare along the Platte. Summer.

43. Cerástium arvénse L. (Mouse Ear Chickweed.) Flowers white with deeply indented petals, styles five, herbage glandular. Clear Creek near Berkeley. 
44. Saponária officinális L. (Bouncing-BET.) Introduced along the D. \& R. G. track near Petersburg. Summer.

45. Saponária Vaccária L. Smooth, diffusely branching, corolla pink, calyx enlarged and angled. Introduced, common around Denver. Summer.

\section{PORTULACÁCEÆ. (Portulaca Family.)}

46. Portuláca olerácea L. (Purslane.) Introduced. Common.

47. Talinum teretifólium Pursh. Leaves fleshy, round linear, flowers small and pink in a cyme. Along the Platte, North Denver near Argo, Riverside Cemetery. Summer.

\section{MALVÁCEÆE. (Mallow Family.)}

48. Sidálcea malvæflóra Moç. \& Sess. (Pink Mallow.) Branching from the base, flowers pink, carpels beaked. Rare along the Platte bottom. Surnmer.

49. Malvástrum coccíneum Gray. (Red Mallow.) Stellately pubescent, flowers light red. On the plains. Summer.

50. Málva rotundifólia L. (Common MaLlow.) Introduced in North Denver.

\section{LINÁCEAE. (Flax Family.)}

51. Linum perénne L. (Blue Flax.) Rare around Denver.

\section{GERANIÁCEAE. (Geranium Family.)}

52. Geránium Fremóntii Torr. (Wild Geranium.) Viscid glandular, flowers pink. Along the Platte. Perrin's meadow. Summer. Rather rare. 
53. Eródium cicutárium L'Her. (Alfilaria.) Recently introduced around Denver.

54. Óxalis corniculáta L. var. strícta SAv. (Yellow OxALIs.) Along the Platte and Cherry Creek near Berkeley. Summer.

\section{VITÁCEæe. (Vine Family.)}

55. Vítis ripária Michx. (Wild Grape.) Along the Platte.

56. Ampelópsis quinquefólia Michx. (Woodbine.) Flowers small and green, fruit purple, leaflets five. Cherry Creek, along the Platte.

\section{SAPINDÁCEÆE. (Maple Family.)}

57. Negúndo aceróides Mønch. (Box-Elluer.) Along the Platte and Cherry Creek.

\section{ANACARDIÁCEæE. (Sumach Family.)}

58. Rhus Toxicodéndron L. (PoIsOn-Ivy or Poison-OAK.) The form near Denver does not climb. Leaflets three. Along the Platte and Cherry Creek, sometimes along the ditches.

59. Rhus Canadénsis Marsh var.trilobáta GraY. A strong scented shrub, flowers numerous, small and greenish yellow, red fruit covered with a pleasantly acid coating.

\section{LEguminós A. (Pulse Family.)}

6o. Thermópsis rhombifólia Nurt. Pods spreading, curved downwards. Cherry Creek along the Platte. Spring.

6r. Thermópsis montana Nutr. This has been reported. 
It can easify be distinguished from $T$. rhombifolia by the strictly upright pods.

62. Sophóra serícea NUTT. Flowers white, pods compressed between the seeds. Common. Summer.

63. Lupinus arqénteus Pursh. (Silvery Lupine.) Perennial, diffusely bránching, leafy, silky canescent, blue flowers in a somewhat thick raceme. Common. Summer.

64. Lupinus pusillus Pursh. (Hairy Lupine.) Anuual, low, racemes short and dense, pod hairy and 2-seeded. In sandy places, North Denver and near Cherry Creek. Rather common. Spring.

65. Trifólium praténse L (RED Clover.). Introduced.

66. Trifólium repéns L. (White Ciover.) Introduced.

67. Trifólium hýbridum L. (Alsike or Swedish Clover.) Introduced sparingly.

68. Melilótu : officinális Wildd. (Yellow SweEt-Clover.) Introduced, rare.

69 Melilótus álba Lam. (SweEt-Clover.) Introduced, very common along the ditches.

7o. Medicágo sativa L. (Alfalfa, Lucerne.) Introduced, common.

71. Psorálea tenuiflóra Pursh. Diffusely branching, flowers blue, rarely white; pod one-seeded, glandular. Summer and fall. Common on the plains.

72. Psorálea lanceoláta Punsh. Erect, branching from the base, flowers white, pod very glandular. Along the Platte. Summer.

73. Dálea alopecuroides WiLLD. Flowers blue or white, small in dense spikes. South Denver on Lincoln Avenue. Along a ditch near the south side of Cherry Creek. Fall. 
74. Petalostémon violáceus Michx. (Crimsox PrairieClover.) Flowers crimson on a cylindrical spike. On the plains. Summer.

75. Petalostémon cándidus Michx. (White PrairieClover.) Flowers similar but white, leaflets more numerous. On the plains. Summer.

76. Petalostémon macrostáchyus TorR. Spikes thicker and longer, corolla greenish white. North Denver. Summer.

77. Amórpha fruticósa L. (False Indigo.) A shrub with spikes of dark purple flowers blooming in spring Along the Platte.

78. Glycyrrhíza lepidó́a Pursh. (Liquorice.) Glandular, flowers greenish white, ripe pods brown covered with hooked prickles. Common.

79. Astrágalus caryocárpus Ker. (Ground Plum.) The earliest Astragalus, with large pink and white flowers and pod like a green plum. On the plains.

8o. Astrágalus Canadénsis L. Tall and branching, flowers greenish white, pods ascending, crowded, two-celled, swollen. Along the Platte. Perrin's meadow.

8I. Astrágalus adsúrgens PaLL. Rather tall; violet flowers in dense capitate spikes, pod two-celled, cross section obcordate. Along the Platte

82. Astrágalus hypoglottis L. Low, with capitate spikes of riolet flowers, pod silky with white hairs. Resembles the preceding, but is much smaller and has a villous pod. Along the Platte.

83 Astrágalus Drummóndii Dougl. Tall, white-hairy, corolla white, calyx black-hairy, pods long and hanging, cross section deeply obcordate. Berkeley. 
84. Astrágalus racemósus Punsh. Corolla pink or white, calyx swollen at one side, pods hanging in a loosely, manyflowered raceme, cross section triangular. Rare along the Platte. Early summer.

85. Astrágalus microlobus Gray. Stems spreading on the ground, canescent, flowers blue, pods reflexed, wrinkled, curved upward, one-celled. The pods have the appearance of small bugs running down the stem. North Denver near Elitch's gardens. Summer.

86. Astrágalus lotiflorus Hook. Low with the inconspicuous yellowish-white flowers and long white hairy pods at the base of the stem surrounded by the leaves, pods one-celled, pointed. Common on the plains. It blooms early in the spring and a second time in the fall.

87. Astrágalus Shortianus Nutr. Low, with large violet flowers clustered near the end of the naked stems. Pods large, leathery, pointed, and strongly curved inward, almost twocelled, wrinkled. Leaves and stem covered with appressed silky hairs. Berkeley. Spring.

88. Astrágalus Párryi Gray. Covered with loosely spreading white hairs, flowers white, tinged with crimson, pod with very long point, curved inwards, wrinkled, almost two celled by the intrusion of both sutures. Spring and summer.

89. Astrágalus sparsifórus Gray. Stems decumbent, pods deflexed, mottled, curved inwards, almost two-celled. Spring and summer. Along the Platte.

9o. Astrágalus píctus GraY.var.filifólius GrAY. Leaves either compound witl thread-like divisions or simple and thread-like, pods inflated, mottled with red, flowers small and white. In sandy places often under sagebrush. Common on the plains. Summer.

91. Astrágalus sericoléucus Gray. Forming dense mats. Berkeley. Early spring. 
92 Oxýtropis Lamberti Gray. On the plains the crimson-flowered variety with decumbent stems prevails but along the Platte in the shade, the flowers are almost white and the plant is quite erect. The large white-flowered variety is one of the loco weeds.

93. Vícia Americána Muhl. (Wild Pea.) Climbing, flowers blue, small. It varies and is common along the streams.

94. Láthyrus ornaíus Nutt. (Wild Pea.) Low and somewhat canescent with appressed hairs. Flowers large resembling the next. Montelair. Early summer.

95. Láthyrus polymórphus NUTT. With strongly veined smooth leaves, more prostrate than the preceding. Common along the Platte and Cherry Creek. Early summer.

96. Ápios tuberósa Moench. (Ground Nut.) Climbing, with brown purple flowers. Near Valverde. Autumn.

\section{ROSÁCEÆ. (Rose Family.)}

97. Prúnus Americána Marshall (Wild Plum.) Along the Platte and Cherry Creek, blooming in early spring.

98. Prúnus Virginiana L. (ChoKe Cherry.) Along the Platte and Cherry Creek, blooming in spring.

99. Rúbus strigósus Mrcux. (Raspberry.) Reported from near Denver by Dr. Smith in "Flora of Colorado."

100. Géum stríctum AIT. Leaves hairy, unevenly pinnate, stems erect, flowers yellow, styles becoming hooked. Along the Platte. Rare.

I01. Fragária Virginiana Milı. var. Illinoénsis GraY. (Strawberry.) Along the Platte.

102. Potentilla argúta PURsH. Stems tall and stout, flow- 
ers clustered near the top, yellowish-white, lower leaves with long petioles. Along the Platte. Rare. Summer.

103. Potentilla Norvégica L. Stems tall and weak, hairy, leaflets three, cut toothed, calyx larger than yellow corolla. Along the Platte. Summer.

ro4. Potentilla rivális Nutr. Similar but not so tall and more slender, leaflets usually five, flowers smaller and more numerous. Along the Platte. Summer.

105. Potentilla Pennsylvánica L. var. strigósa Pursh. Stems erect, leaves close to the stem, pinnate leaflets divided into linear divisions with revolute margins. Flowers clustered at top of stems. Near the Platte in South Denver. Summer.

106. Potentilla grácilis Dougl. Branching from the base, tall. Root leaves with long petioles and about seven palmate leaflets, very white on the under surfaces, flower branches spreading. Perrin's meadow. Nortlı Denver.

107. Potentilla fruticósa L. (Shrubby Potentilla.) This was peported from near Denver by B. H. Smith in "Flora of Colorado." I think I saw it many years ago in North Denver but have not seen it since.

108. Potentilla Anserína L. (SIlver-WeEd.) Spreading by runners, leaves silky and white. Common in wet places. Spring and summer.

rog. Rósa blanda Aıt. The common wild rose: Along the Platte and Cherry Creek.

110. Rósa Sáyi. This has been found by Miss E. Eaton along Clear Creek near Berkeley.

\section{SAXIFRAGÁCEÆ. (Saxifrage Family.)}

III. Saxifragá nivális L. Very rare along the Platte near Valverdé. 
112. Ríbes flóridum L. Racemes drooping, leaves sprinkled with resinous dots, berry black. Along the Platte.

113. Ríbes aúreum Pursh. (Golden Currant.) Smooth, yellow flowers, numerous, fragrant, berry at first yellow, turning black. Along the Platte.

\section{LYTHRÁCEÆ.: (Lythrum Family.)}

114. Ammánia latifólia L. Along the Platte. Summer.

115. Lýthrum alátum Pursh. Along the Platte near the C. C. Bridge. Summer. Rare.

\section{ONAGRÁCEÆ. (Evening Primrose Family.)}

I16. Epilóbium spicátum LAM. (Willow Herb, FireWeed.) Flowers crimson, large white style deflexed. Clear Creek near Berkeley. Summer.

117. Epilóbium colorátum MuHL. Along the Platte and - Cherry Creek. Sometimes along the ditches.

118. Epilóbium adenocaúlon Hausskn. Found in the same localities as the preceding and similar. It differs most noticeably in the more glandular pubescence, leaves less serrate and the coma of the seeds whiter.

119. Epilóbium paniculátum Nutr. Stem erect, branching above, annual. Leaves and flowers small and branches almost leafless. Clear Creek near Berkeley. Along the Platte. Summer.

120. Gayóphytum ramossissimum Torr \& GraY. Diffusely spreading, with slender, reddish branches, flowers very small, pink. It might be mistaken for Epilobium paniculatum but can always be distinguished by the lack of coma on the seeds.

121. CEnothéra biénnis L. Erect and stout with yellow flowers that open about sunrise. The var. grandiflora Lindl 
has flowers much larger and is not so stout. Denver. Summer.

I22. Enothéra pinnatifida Nutt (The Common WhiteFlowered Evening Primrose.) Ascending stems branching from near the ground. Seeds in two rows in each cell. Common on the plains. It has two seasons of blooming. The spring flowers are from plants of the previous year, while the fall are seedlings of the same season.

123. Enothéra albicáulis Nutt. (White-Stemmed Evening Primrose.) Tall stems white, branching, calyx tips free in the bud. Flowers white. Along the Platte, and in sandy places in North Denver. Summer.

124. Enothéra coronopifólia T. \& G. (Small White Evening Primrose.) Flowers white, nearly an inch in diameter, becoming a bright pink in drying. Stems erect and leafy, with small, pinnate leaves, divisions almost linear. Common. Spring and summer.

125. CEnothéra brachycárpa Gray. (Golden Evening Primrose.) Leaves and flowers from a perennial woody root. Flowers yellow, turning purple in fading or drying, very large, three to four inches in diameter. This handsome Enothera has been found near Sloan's Lake. It is rare around Denver, but abundant on Rooney's Ranch near Morrison. Spring.

126. CEnothéra serruláta Nutr. Many erect stems from the woody root. Small yellow flowers numerous and in the upper axils. Along the Platte. Summer.

127. Gaúra parviflóra Dougl. Tall, sometimes five feet. Leafy at base, branching above. Small pink flowers in spikes which become longer in fruit. Common. Summer.

128. Gáura coccínea Nutt. (Red Gaura.) Low and spreading, flowers pink becoming red. Common. Spring and summer. 


\section{LOASÁ́CEÆ. (Mentzelia Family.)}

129. Mentzélia albicáulis Dovaц. Erect with simple or branching white stems, flowers small and yellow, seeds warty. Along the Platte. Spring and summer.

130. Mentzélia núda T.\& G. (Evening Star.) Stems erect and branching above. Large yellowish white flowers with filaments numerous and like the petals. Seeds winged. Common. Summer and fall.

131. Mentzélia multiflóra Gray. Stems branching difusely. Flowers numerous, bright yellow. Seeds winged. Along the D. \& R. G. track near Valverde Bridge and the South Park track at Valverde. Summer.

\section{CUCURBITÁCEÆE. (Squash Family.)}

132. Echinocýstis lobáta Torr. \& Gray. (Wild CucumBer Vine.) Common in cultivation. Wild along the Platte. Summer.

\section{CACTÁCEÆ.}

133. Mamillária vivipára Haw. (BIRd's-Nest Cactus.) Globose, flowers rose color, fruit a berry. On the North Denver hills. Spring.

134. Mamillária Missouriénsis SweEt. Globose, flowers yellow, berries scarlet. North Denver hills. Spring.

135. Céreus viridiflórus EngeLm. Globose, flowers greenish, radiating spines white and purple, central spine long, white, spreading outward and upward. Hills near Berkeley. Spring.

136. Opuńtia Rafinésquii Engelm. (Prickly-Pear.) The flat jointed cactus with clusters of spines sparingly scattered and yellow flowers. Berry becoming fleshy and often red. Edible. Along the Platte and on the plains. 
137. Opuntia Missouriénsis DC. (Common Cactus.) 'The common flat-jointed cactus with numerous clusters of spines. Flowers yellow, rarely red near Denver. Fruit dry. Common on the plains, blooming in early summer.

\section{UMBELLÍFERÆ. (Parsley Family.)}

138. Heracléum lanátum Michx. (Cow-Parsirip.) Tall and stout, large ternately compound leaves with broad leaflets, many rayed umbels of white flowers. Along the Platte and Cherry Creek. Summer.

139. Peucédanum nudicáule NutT. On thehills at Berkeley in spring.

140. Cymopterus glomeratus RAF. The earliest bloomer on the plains. Low with white flowers and shiny compound leaves. .Carpels winged.

141. Cymópterus montánus TorR. \& Gray. Similar to preceding, flowers pinkish and leaves glaucous. In North Denver. It is likely to be found where the soil is adobe. "Early spring.

142. Musénium trachyspérmum NutT. Low branching from near the root, flowers yellow, fruit rough. North Denver and Valverde hills. Spring.

143. Cicúta virósa L. var. maculáta Coulter \&. Rose. (Poison-HemLock.) Stout and tall, leaves twice or thrice pinnate with lanceolate-acuminate serrate leaflets. A flat-topped umbel of white flowers. This grows in the water and is found along Cherry Creek and the Platte. Summer.

144. Bérula angustifólia Косн. A slender, branching marsh plant with pinnately compound leaves, leaflets from toothed to incised. Flowers white, involucre and involucels present.

I45 Pastináca satíva L. The common parsnip. Introduced. 


\section{CORNÁCEAE.}

146. Córnus stolonifera Michx. (Dogwood.) A shrub with reddish stems, cymes of white flowers and fruit white or lead color. Along the Platte. Summer.

\section{CAPRIFOLIÁCEEE.}

147. Symphoricárpos occidentalis Hooker. (SNowberRy.) A shrub with thickish leaves, corolla pink, thick, white hairy within. Berries white. Along the Platte.and Cherry Creek. Summer.

148. Lonicera involucráta BANks. This was reported from near Denver by Dr. Smith in the Flora of Colorado. I have not found it in the locality.

$$
\text { Rubizceate }
$$

149. Gálium Aparíne L. (Cleavers.) With long clinging stems barbed on the angles of the stems, the margins and mid. ribs of the leaves; leaves about eight in a whorl. Fruit bristly. Along the Platte. Summer.

150. Gálium boreále L. Erect, small white flowers in a panicle. Leaves in whorls of four. Along the Platte. Summer.

\section{COMPÓSIT E.}

151. Kúhnia eupatorioídes L. Thereare two varieties; one lias erect stems and few flowers at summit; the other has stems spreading and ascending, flowers numerous. Along the Platte and on the plains. Fall.

152. Brickéllia grandiflóra NuTr. Stems branching from the base, leaves triangular-ovate, crenate, dentate bracts of involucre striate. Along the Platte. Rare. Summer. 
153. Liátris punctáta Hooker. (Prince's-Plume.) Stem simple, leaves linear, stiff and spreading, purple flowers in a dense spike, pappus plumose. On the plains. Fall.

154. Gutierrézia Euthámiæ T. \& G. Many stems from near the root, leaves narrowly linear, more glutinous around the cymes of small yellow heads; pappus chaffy. Along the Platte in the fall.

155. Grindélia squarrósa Dunal. (Gum-Plant, RosinWeED.) Erect. Involucre very viscid and with recurved tips, flowers yellow. Common until late in the fall.

156. Chrysópsis villósa Nutt. (Golden Aster.) Many stems from the root, hairy, yellow flowers clustered near the ends of the stems. Common on the plains. Summer and fall.

157. Aplopáppus rubiginósus Torr \& Gray. Resembling Grindelia squarrosa. Erect, paniculately branched, leaves spiny-toothed, viscid with glandular hairs. Easily distinguished from the Grindelia by the bristly pappus. North Denver. Riverside cemetery. Summer and fall.

158. Aplopáppus spinulósus DC. Stems branching from base, ascending, lobes of the pinnate leaves and bracts of the involucre bristle-tipped. Common on the plains. Summer to fall.

159. Bigelóvia gravéolens Gray. Shrubby and bushy, leaves and stems usually white, yellow flowers clustered in cymes at the ends of stems. Common on the plains. Fall.

r6o. Solidágo Canadénsis L. (The TALL GoLden-Rod.) Along ditches and streams. Summer to fall.

16r. Solidágo nemorális Art. var. incána GrAY. Low with leaves an inch or more wide, not decreasing much upwards. Inflorescence more compact. Along the Platte. Summer to all. 
162. Solidaǵo rígida L. Stem stout, simple, heads in a cyme, herbage scabrous and whole plant stiff. Perrin's meadow in North Denver. Summer, fall.

163. Solidágo occidentalis Nutr. Spreading, leafy, with small clusters of fragrant flowers at the ends of the branches, receptacle hairy or fringed. Growing near water. Fall.

164. Townséndia sericea Hook. Large pink flowerssessile and surrounded by the leaves. Growing close to the ground and inclined to form small mats. In early spring in North Denver.

165. Áster Féndleri Gray. Tall, branching above, bluerayed flowers almost sessile on short branchlets, leaves clasping by an auriculate base. Along the Platte. Fall.

r66. Áster ericoídes L. Diffusely branching, leaves linear, rays white. Along the Platte. Fall.

167. Áster multiforus AIt. Branching from the base, whiteradiate heads crowded on the branchlets. Common. Fall.

168. Áster salicifólius AIт. Tall, leaves long and pointed, purple-rayed flowers rather large in a panicle or thyrse. Along the Platte. Fall.

I69 Áster angústus T. \& G. Numerous branches erect along the stem, heads rayless, on short stems, pappus soft and snowy white. In wet places in North Denver and along the Platte.

170. Áster canéscens Pursh. var. latifolius Gray. Stems a foot or two high. The common deep purple aster, glandular, involucre with recurved tips. Fall.

171. Áster tanacetifólius HBK. Stems low and spreading, leaves pinnatifid, flowers large, rays purple. Spring to fall. 
172. Erígeron glabellus Nutr. Tall, leafy-stemmed, heads nearly an inch in diameter, rays blue, numerous. Rare along the Platte but common in the mountains. Summer.

173. Erigeron púmilus Nutr. Low with many stems from the root, very hairy, heads glomerate, flowers clustered at tops of the stems. Common on the plains. Spring.

I74. Erígeron compósitus PURsh. var. trífidus GRAY. Forming mats on gravelly hills, the white-rayed heads on scapelike peduncles. It has two seasons, blooming early in thespring and also in the fall if the season is not too dry. Riverside cemetery. North Denver.

175. Erígeron cánus Gray. Stems several from the root from 6 in. to a foot high. Entire plant canescent with fine white appressed hairs. Rays white or pink. Near Berkeley, not common. Spring to summer.

176. Erígeron flagelláris Gray. Easily distinguished by the long prostrate runner-like stems which root at the joints, flowers small, rays white or pink-tipped. Along the Platte and Cherry Creek. May and June.

177. Erígeron Bellidiástrum Nutr. Diffusely branching, annual. Small heads very numerous, rays paleblue. Common. Summer.

178. Erígeron strigósus MUHL. Annual, from one to three feet high, slender and branching near the top. Heads small, rays white. Along the Platte. Summer.

179. Erígeron Canadénsis L. Annual, flowers very small and numerous, rays inconspicuous. A common weed. Summer to fall.

180. Erígeron divaricátus Michx. With very small purplish rays, numerous branches ascending. 
181. Antennária dioica Gerts. (Everlasting-Flower.) Forming mats, bracts of the involucre papery, white or pink, flowering stems low. North Denver and Berkeley. Spring.

182. Antennária plantaginifolia Hook. Similar to the above, flowering stems much taller and heads smaller. Clear Creek. Not common. Summer.

183. Gnaphálium Sprengélii Ноок. \& ARx. Stems leafy, leaves sessile covered with loose white wool. Heads clustered at top of stems, bracts of the involucre yellow becoming brownish. North Denver. Fall.

184. Gnaphálium stríctum Gray. Wool of stem and leaves close, flowers clustered along the stem at the axils, bracts of involucre brownish. Along the ditches. Summer and fall.

185. Íva xanthiifólia NuTt. A tall coarse weed with opposite broad coarsely serrate leaves, heads panicled at top of stem often becoming a dark brown. Summer and fall.

186. Íva axilláris Pursh. About a foot high, drooping heads solitary in the axils of the leaves. North Denver. Summer.

187. Ambrósia tríida L. (RAGweed.) Tall, opposite leaves deeply three or at base five-lobed, fruit with spiny projections. Common. Fall.

188. Ambrósia artemisiæfólia L. Branching diffusely above, leaves dissected into narrow divisions, fruit clustered, short-spined. Common. Fall.

189. Ambrósia psilostachya DC. This is found with the preceding but can easily be distinguished. At the lower part of stem, divisions of leaves broader; fruit solitary and without spines.

Igo. Franséria Hookeriána Nutr. Branching diffusely, leaves bipinnatifid broad, white hairy; spines of the fruit recurved, awl shaped. North Denver. Fall. 
rg1. Xanthium Canadense Mrll. (Cockle-Bur.) Common along the streams, fall.

192. Rudbéckia hirta L. (Cone-Flower.) Erect, rough hairy, rays yellow; disk brownish-purple, thimble-shaped. Along the Platte. Summer.

193. Lépachys columnáris Torr. \& Gray. (ColumnFlower.) Stems rather tall, usually several from the root, heads often solitary, yellow rays reflexed, disk columnar, dark brown. Along the ditches and on the plains. Common. The var.pulcherrima Torr. \& Gray is also found. It has the rays wholly or in part brownish purple. Along the Platte, less common. Summer.

194. Lépachys Tagétes Gray. Leaves with stiff lobes, white bristly,smaller than the preceding. Heads much smaller, rays very dark brown. Rare in North Denver, near Rocky Mountain Lake. Fall.

195. Gymnolómia multifóra BeNTH. \& Hook. Simple stemmed or much branched, usually with numerous heads of yellow flowers an inch in diameter. Smaller and more slender than the sun-flower. Along the Platte, summer and fall.

196. Heliánthus annuus L. (Sun-Flower.) The common large flowered and large broad-leaved sun-flower. Summer to fall.

197. Heliánthus púmilus Nutr. Chiefly branched from the base, very stiff, with thick stiff rough leaves, disk yellow. Berkeley Hills. Summer and fall.

198. Heliánthus petioláris NuTr. A foot or more high, branching, heads usually solitary on the branchlets, disk dark brown, heads $1 \frac{1}{2}-2$ inches in diameter. The common sunflower of the plains. Summer to fall. 
199. Heliánthus Maximiliáni Schrad. Stem very tal ${ }^{l}$ and rough, leaves thick, lanceolate, sparingly serrate, usually keeled, flowering branches at the top of the stem. North Denver recently introduced.

200. Verbesina encelióides CAv. Usually branching, leaves ovate, unevenly serrate, canescent; rays 3-cleft, akenes flat, broadly winged. . Introduced within six years, very common especially in North Denver. Summer and fall.

20r. Coreópsis tinctória NuTr. Usually tall and branched above. Yellow rays brown near the base, disk dark. Rather rare. Along the Platte. Summer.

202. Biọ́ens frondósa L. (Stick-Tight.) Heads rayless, akenes hairy 2-awned. Along the ditches, common, late summer and fall.

203. Bidens cérnua L. Heads nodding after the rays have withered. Summer and fall. In marshy places along the Platte.

204. Bídens chrysanthemoides MICHX. (BUR-MARIGOLD.) Heads large with conspicuous rays not nodding. Common along the ditches. Fall.

\section{Bídens tenuisécta Gray. (Spanish-Needles.)} Leaves pinnately dissected into narrow divisions, rays yellow, longer than the disk, akenes smooth 2-awned. Along the ditches, late summer.

206. Thelespérma ambíguum Gray. Diffusely branching, a foot high, flowers numerous, rays yellow, disk yellow, divisions of the leaves narrowly linear. This is usually called Coreopsis and is common around Denver. Summer.

207. Thelespérma grácile GRAY. Tall, opposite leaves scattered, heads rayless, disk yellow turning darker. North Denver. Summer. 
2c8. Báhia oppositifólia Nutr. Stems low, with many erect branches white-pubescent, rays few and small, heads small. This forms patches in damp, alkali spots. North Denver. Valverde. Summer.

209. Báhia chrysanthemóides Gray. Compound leaves clustered near the root, more scattered and much smaller along the stem, which is diffusely branched above. Rays yellow, spreading. The head has the appearance of a yellow broadrayed daisy. Rare along the Platte. Late summer.

210. Hymenopäppus filifolius Hook. White-woolly, leaves pinnately twice parted into narrow divisions, heads rayless, numerous on the slender almost leafless stems. Valverde Hills. Summer.

211. Chænáctis Douglasii Hook. \& Ars. Leaves scattered near the root, twice parted into thick blunt divisions, white cottony heads in a diffuse cyme, rayless, akenes with chaffy fringed scales. Valverde Hills. Summer.

212. Helénium autumnále L. (SNEEze-WeEd.) Stems tall, leafy, simple below, winged; heads cymosely arranged, disk yellow and globular, rays small 3-lobed, yellow, reflexed. Along the Platte near Valverde. Fall. Not common.

213. Dysódia chrysanthemoides LaG. (Fetid-MariGOLD.) Low, diffuse with ascending branches, whole plant dotted with brown glands which are largest on the rays. Pappus purple-tipped, heads numerous on short branchlets, odor very strong and unpleasant. Along the ditches. Common. Fall.

214. Hymenathérum aúreum GRAY. Low, much branched, leaves alternate, pinnately parted into blunt filiform divisions, rays yellow, pappus of fringed scales. Odor not unpleasant. A few plants used to grow in the vacant lots on Stout Street between 'Twenty-third and Twenty-fourth Streets. Summer. 
215. Ánthemis Cótula L. (Mayweed.) (Dog-Fexven.) Sparingly introduced. North Denver.

216. Achilléa Millefólium L. (YARrow.) Rays of small heads from white to rose color. Along the Platte, Clear Creek, and Cherry Creek. Summer to fall.

217. Chrysanthemum Leucánthemum L. (OX-EYE DAIsy.' White WeEd.) Sparingly introduced along the Platte.

218. Artemísia biénnis Willd. Wormwood. Stem usually solitary, very leafy panicle pyramidal, the small greenish brown almost sessile heads crowded on the branchlets. Common. Summer and fall. Strong odor.

219. Artemisia frígida Willd. Stems many from the root, very white with silky hairs, about a foot high; leaves much divided into linear lobes, heads panicled, loosely clustered on the branchlets, drooping. Common on the plains and in the mountains. It is used as a tea in mountain fever. Summer and fall.

220. Artemisia Canadénsis Michx. Leaves clustered at the root twice parted into linear lobes, upper leaves more simple and somewhat white-woolly, panicle narrow, heads small and smooth, slightly drooping. Along the Platte. Fall.

221. Artemísia tridentáta Nutr. (Black Sage.) Much branched, woody, canescent leaves with three obtuse teeth or lobes at the truncate apex. North Denver. Fall.

222. Artemísia Ludoviciána NuTr. Branching somewhat from the base, herbage very white with cottony pubescence which can be rubbed off, branches of the panicle erect, heads almost sessile and erect, leaves entire or few toothed. Common. Fall. 
223. Artemísia filifólia Tork. Shrubby, branches very numerous from the lower stems, slender leaves 2 to 3 -parted or entire with filiform divisions, heads very small, short; racemes of the narrow panicle surpassed by the leaves at the base. Whole plant whitened with close minute tomentum. Common in North Denver. The flower buds often become infested with a gall fly the larvæ of which inhabit the buds. Fall.

224. Artemisia dracunculoídes Pursh. Smooth with leaves either entire or 3-cleft, branching, with many small heads. On the Denver plains.

225. Senécio aúreus L. var. compactus Gray. One of the numerous varieties of this variable species. Low, sparingly woolly, leaves irregularly lobed; thickish heads in a spreading cyme; rays and disk yellow. The early and common spring Senecio.

226. Senécio Douglásii DC. Stems usually many from the root, leafy with pinnately parted leaves, divisions long and linear, thick, rays yellow, $\frac{1}{3}$ inch long, heads in a spreading many-flowered cyme. Common in the fall.

227. Cnicus ochrocéntrus Gray. - (Thistle.) Stout, leaves and stem white tomentose, prickles long and yellow; disk white or crimson, bracts of the involucre sticky, tipped with a broad stout spreading yellow prickle. Common in early summer.

228. Cnícus undulátus Gray. Similar, but neither so tall nor so stout, heads smaller, prickles of the involucre short and rather weak. In North Denver. Fall.

229. Cichórum Intybus L. (CHICORY.) Introduced around Italian gardens in North Denver.

230. Stephanoméria runcináta NuTr. Diffusely spreading, small pink flowers, numerous near the ends of branches, 
which are almost leafless, or with bract-like leaves. It can readily be distinguished from Lygodesmia by the plumose pappus instead of hair-like bristles. Near Denver. Summer.

23r. Tragopógon porrifólius L. (OYster-Plant, Sa Lsify.) Escaped from cultivation. Summer.

232. Crépis intermédia Gray. Ashy, leaves oblonglanceolate in outline, irregularly dentate or laciniate, tapering; heads of yellow flowers in a corymb; akenes almost black, ten-ribbed; pappus about equaling akenes, very soft and white. Berkeley. Spring.

233. Lygodésmia juncea Don. Diffusely branching from a perennial root, stems striate, leafless except for occasional scale-like leaves; lower leaves parted, divisions linear, rays. pink. Common and variable in flowers, leaves, and stems. Summer.

234. Lygodésmia rostráta Gray. Annual, erect, leafy heads small, numerous in a corymbed panicle with erect branches; akenes tapering at summit, rays light pink soon fading. North Denver. Along the Platte near Valverde. Late summer.

235. Tróximon gláucum Nutt. (Prairie-Dandelion.) Perennial, without a stem; leaves linear-lanceolate, wavy margined, somewhat white woolly; large heads of yellow flowers with rays often brown-tinged. On the plains in early spring. A variety of this variable species is found along the Platte under the trees. It has very long leaves sparingly laciniate, and small long-stalked heads of brownish flowers.

236. Taráxacum Officinále WeBer. The common Eastern dandelion introduced in grass seed. Along the ditches and on lawns, etc. 
237. Lactúca Canadénsis L. Usually tall, sometimes nine feet; leaves hairy on the midvein, runcinate pinnatifid; heads small, crowded in a diffuse panicle, rays yellow. Along the Platte. Summer.

238. Lactúca Ludoviciána DC. Stem erect, simple to the diffusely branching almost leafless panicle; leaves veiny, auriculate clasping, spiny on the midrib and spiny-toothed on the margins; heads of small yellow flowers numerous expanded for a short time in the morning. They seem like little stars all along the stem. Coinmon in waste grounds. I believe that it is introduced around Denver.

239. Lactúca pulchélla DC. Bright blue flowers conspicuous in the morning; rays nearly half an inch long. It looks like an aster, but the flowers all have rays, and the juice is milky. Common along streams. Summer.

240. Sónchus oleráceus L. (Sow-Thistle.) Introduced sparingly.

241. Sónchus ásper Vill. (Spiny-Leaved Sow-Thistle.) Sparingly introduced.

\section{LOBELIÁCE E.}

242. Lobelia syphilítica L. Simple-stemmed, flowers blue, sometimes rose colored or white, in racemes, found in swampy places in the fall. It might be mistaken for a Penstemon, but can readily be distinguished by the milky juice and the corolla open to the base on one side.

\section{CAMPANULÁCEA.}

243. Speculária perfoliata A. DC. I found a plant years ago along the Platte near the ( $\mathrm{C}$. Bridge. I have not seen it since. 
244. Campánula rotundifólia L. The common hair-bell, with erect buds and nodding capsules. Along the Platte. Summer.

245. Campanula aparinóides Pursh. Flower buds drooping, capsule erect; corolla smaller and more deeply cleft than the preceding. Along the Platte. I found this several years ago near Smith's Bridge, but have not seen it since.

\section{PRIMULÁCEA.}

246. Steironéma ciliátum RAF. Branching; yellow flowers solitary in the axils on long pedicels, nodding. Summer.

247. Glaux maritima L: Stems many from the root, which has running root-stalks; leaves somewhat fleshy, flowers small, pink, sessile in the axils of the numerous leaves. Along the Platte near the Twenty-third Street viaduct in a low, damp place. Spring.

\section{APOCYNÁCEAE. (Dog-Bane Family.)}

248. Apócynum androsæmifólium L. Diffusely branched above, drooping clusters of small bell-shaped pink flowers near the ends of the branches. Rather rare. Berkeley, near Clear Creek.

249. Apócynum cannábinum I. Tall and erect, branching near the top; small white flowers in a close cyme. Common in wet places along the Platte, and sometimes along the ditches. Perrin's Meadow, in North Denver.

\section{ASCLEPIADÁCEAE. (Silk-Weed Family.)}

250. Asclépias speciósa Torr. (Milkweed.) Tall and simple-stemmed, leaves large and leathery, short petioled; flowers large, pink and purple; pods large, erect on deflexed pedicels, covered with soft prickle-like processes. Common. Summer. 
251. Asclépias verticilláta L. var. púmila GRAY. Low, with crowded filiform leaves; umbels near the top of simple erect stems; flowers small and white. Rather common near City Park. North Denver. Summer.

252. Asclépias auriculáta ENGelm. Leaves very long and linear, alternate and numerous, flowers in close umbels in the axils, not numerous, flowers greenish. This is the Acerates auriculata Engelm of Coulter's Manual. It has recently been united with Asclepias stenophylla Gray, under the oldest name. Rather common, North Denver, near Valverde, and toward Montclair. Summer.

253. Acerátes viridiflóra Ell GRAY. Leaves ovate or oblong-lanceolate, umbels few, flowers greenish. Rare, Berkeley, near Clear Creek, Valverde. Summer.

\section{GENTIANÁCEæE. (Gentian Family.)}

254 Eustóma Russelliánum Griseb. Glaucous, simplestemmed except above where the inflorescence usually becomes loosely cymose, flowers often solitary; corolla large, funnelform with a spreading border, divisions blue with a dark spot at base, fringe toothed at the top. This is a biennial, and is rare. I found it near the boulevard in North Denver several years ago. The low, wet place was filled up, and it was buried. This year I found it at Valverde, a single plant. It was also found by Miss Helen Thompson on their ranch out on the Broadway road not far from Denver.

255. Gentiána calycósa Griseb. (Blue-Gentian.) This has large tubular blue corollas that do not spread open. The flowers are few, clustered in the upper axils. This was found by Miss E. Eaton along Clear Creek, about six miles from the city: Summer.

\section{POLEMONIÁCEÆ.}

256. Phlox Douglásii Hook. 'This is low and spreading, with salver-shaped pink flowers. Rare near Denver, but formerly common along Park Avenue. Spring. 
257. Gília lineáris Gray. Usually simple-stemmed, sometimes branched diffusely from near the base; sticky, especially around the flowers, corolla pink, with yellow tube, small. -Along the Platte; Clear Creek, near Berkeley. Summer.

258. Gilia grácilis Hook. Low and spreading; flowers scattered, numerous, very small, pink with yellowish tube; capsules becoming large and noticeable; seeds without mucilage. Common in early spring on the plains.

259. Gília longiflóra Dox. Diffusely spreading, flowers very numerous on slender stalks, corolla pale blue or white, salver form with a long tube. Spring to fall. Often with flowers and dry seed pods on same plant.

260. Gilia púngens Benth. Low and spreading, with woody stems; leaves spiny, numerous, and small; corolla white, fragrant This blooms in the evening and the flowers close the next morning. The plants have the appearance of tiny Coniferæ. Common on the plains. Early summer.

26r. Gilia aggregata Spreng. (Red Gilia.) Stems tall, simple, or branching; the long salver-form scarlet or white corollas in a close panicle, leaves with narrow linear divisions. Along the Platte. Summer to fall.

262. Gilia pinnatifida Nutr. Leaves clustered at the root, stem simple and branched above, or sometimes diffusely spreading from the base. Flowers very numerous in a much branched panicle. Corolla white-veined or mottled with light blue. Stamens with blue filaments, anthers conspicuous and longer than the corolla. Along the Platte and Cherry Creck, Clear Creek. Summer to fall. It grows in sandy places along the river bottom.

263. Gilia inconspícua Dougl. Slender, erect, branching above, about a foot high; leaves once or twice pinnately divided into short, narrow, bristle-pointed lobes; corolla small, 
light blue with yellowish tube; whole plant somewhat sticky. Formerly common near the old Ladies' Relief Hospital. Spring and early summer.

264. Polemónium foliosissimum Gray. Sticky, leafystemmed, flowering stems arranged in a cyme; flowers numerous, blue, about one-half inch in diameter, style longer than the filaments and exceeding the corolla. Along Clear Creek, near Berkeley. Rare.

\section{HYDROPHYLLACEÆE. (Water-leaf Family.)}

265. Ellísia Nyctélea L. Tender and succulent, diffusely spreading, leaves pinnately parted, flowers usually solitary in the axils, small corolla light blue or white exceeded by the calyx. Common on the plains and along the streams. Spring and summer.

266. Phacélia circinata $J_{A C Q} f$. This is a coarse-looking perennial, many-stemmed from the base, whitish with bristly hairs; leaves broad lanceołate, often with one or two pairs of small leaflets at base of petiole. Inflorescence circinate, densely flowered, very bristly, corolla white or rarely violet, with stamens extending beyond. Common along the Platte and Cherry Creek, also along the ditches. Summer.

267. Phacelia Neo-Mexicána Thurber. Hairy and sticky, leaves twice pinnatifid with blunt lobes. Found in fruit along the Platte beyond Overland Park. Coulter's Manual describes the flowers as white with the stamens much exserted. Spring and summer.

\section{BORAGINÁCE $Æ$.}

268. Heliotropium Curassávicum L. Smooth, glaucous and fleshy, diffusely spreading, flowers white with a yellow center, in a dense circinate cluster, becoming black in drying. Near Sloan's Lake. Summer. 
269. Echinospérmum Redówskii LEHM. var. occidentale Watson. (Beggar-Lrce.) Easily known by the small, light blue flowers and the small sharp-awned burs. Very common on the plains.

270. Krynítzkia crassisépala TorR. \& GRAY. Diffusely branching, round and becoming a tumble weed, white with bristly hairs, very rough, calyx becoming thick at the base and inclosing the nutlets; one is smooth and the rest are white, warty. On the plains. Summer.

271. Krynitzkia Pattersóni Gray. Branches more slender. Flowers much smaller, calyx not so thickened, akene usually only one, smooth. Similar to the above in other characteristics. North Denver. Summer.

272. Krynitzkia Jamésii Tork. White hairy with close hairs which become bristly and spreading when the fruit is ripe. Flowers with yellow appendages in the throat, nutlets narrowly margined, smooth and shining, flattened on top in two pairs. North Denver, on the plains: Summer.

273. Krynítzkia virgáta Porter. Taill and columnar, blooming from near the base of the simple stem, flowers clustered in the axils of the leaves, white corollas with ten small scales within the tube, very bristly, especially when old. Along the Platte and Cherry Creek. Summer.

274. Merténsia lanceoláta DC. (Bluebells.) Glaucous, branching from the base, flowers in a close panicle which becomes loosely spreading with age, corolla blue. Clear Creek near Berkeley. Along the Platte near Overland Park. Spring.

275. Lithospérmum pilósum NutT. Reported from near Denver by Dr. Smith and B. H. Sinith in the, Flora of Colorado of Parry and Coulter.

276. Lithospérmum hírtum Lens. Found near Denver by Dr. Smith. 
277. Lithospérmum angustifólium Micнx. Branching from the woody root, corolla large, bright yellow, tube long, flowers clustered at the top of the stem, the later plants spreading diffusely with inconspicuous flowers. Common, the large flowered blooming in spring, the small flowered in late summer or fall.

278. Onosmódium Caroliniánum DC. Stout and rough, corolla tubular with green lobes, hairy stigma protruding. common along the Platte and on the plains where it is not too dry. summer.

\section{CONVOLVULÁ́CEA. (Morning-glory Family.)}

279. Ipomœ́a leptophýlla Torr. (The Morning-glory BusH.) This is easily known by its spreading branches from an immense taproot, its linear leaves, and numerous large, crimson, funnel-shaped flowers. Never found far from water, but on the open plains. Summer.

280. Convólvulus sépium L. (MORNing-GLORY Vine.) Climbing over the shrubs, etc., along the Platte and Clear Creek. The var. repens Gray, is prostrate and white pubescent It grows in fields. Summer.

281. Convólvulus incánus VAHL. Stems slender, running along the ground or over low herbs, leaves various, usually arrow-shaped, corolla not an inch across, white, tinged with pink. Calyx free from bracts.

282. Evólvulus argénteus Pursh. Low, branching from the base, erect, densely covered with soft, long appressed hairs, flowers axillary on short stalks which are deflexed in fruit, corolla rose color or blue. On the plains, rather common. Summer.

283. Cúscuta decóra Chorsy. (Dodder.) A parasite with yellow stems and clusters of white, waxy flowers. It apparently grows on all kinds of herbaceous plants. Summer. 
SOLANÁCEA. (Potato Family.)

284. Solánum triflórum Nutt. (Night-Shade.) Berries green when ripe. Common. Summer to fall.

285. Solánum nigrum L. Berries almost black when ripe, smaller than the preceding. Common. Summer to fall.

286. Solanum rostrátum DUNAL. Very bristly, especially the calyx, which incloses the fruit, flowers bright yellow, sterile filament beaked, often tinged with purple; flowers numerous in a raceme. Common along ditches. Summer to fall.

287. Phýsalis anguláta L. (Ground-CHERry.) Reported by Dr. Smith.

288. Phýsalis pubéscens $L$. Whole plant viscid; leaves very broad, almost round, entire or with a few blunt teeth along the sides; flower yellow, with a dark eye. Summer and fall.

289. Phýsalis Virginiána L. Viscid, leaves rather crowded, much smaller than the preceding; flower larger, with a dark eye. Summer and fall.

290. Phýsalis lanceoláta Michx. Not viscid, leaves usually lanceolate and wavy margined, sometimes ovate. Summer and fall.

29r. Phýsalis lobáta Torr. Covered with little white grains, leaves mostly sinuate, prostrate, flowers purple or white. North Denver. Summer.

292. Datúra Stramónium L. (ThoRN-A PPLE.) (JAMESTOWN-WEED.) Introduced along the Burlington railroad track, near Thirty-first Street. It has also been found along Cherry Creek, and is quite abundant at Golden.

\section{SCROPHULARIÁCEÆE. (Figwort Family.)}

293. Scrophulária nodósa L. Tall, flowers in a long panicle at the top of the stem, corolla dull purple. Common along the Platte and Cherry Creek. 
294. Penstémon glaber Pursh. Stems usually several from the root, glaucous, corolla swollen above the tube, sterile filament with a few hairs at top, leaves broad and clasping Common along the Platte in sandy places. Summer.

295. Penstémon secundiflórus Bentr. Tall, stem leaves linear-lanceolate, the pairs an inch or two apart, flowers blue or purplish, in a one-sided thyrse, sterile filament dilated at the tip, and usually smooth. Along the Platte and Clear Creek, generally in the shade of the trees. Summer.

296. Penstémon acuminátus DougL. Glaucous, stem leaves ovate-acuminate, clasping; flowers in an interrupted thyrse, corolla lilac to a darker shade, sterile filament densely bearded, curved. This grows on hillsides, Valverde, Berkeley. It is earlier than the two preceding, and in bloom in May and June.

297. Penstémon cærúleus Nutr. Stems simple, erect, densely flowered; corolla azure, leaves and stem glaucous, leaves lanceolate and long, often somewhat keeled. Common on the plains in spring.

298. Penstémon álbidus NuTr. ' Viscid all over, about a foot or so high, flowers whitish. Rather common on the plains. Spring.

29ọ. Penstémon grácilis Nutro. This has serrate leaves and a lilac corolla. Found by Miss Eaton on Clear Creek.

300. Mímulus Jámesii Torr. \& Gray. Leaves far apart on the long slender stems, round and often slightly reniform, flowers yellow. Along the Platte and Clear Creek. Summer.

301. Mímulus ríngens L. Stems tall and erect, angled, simple, flowers blue, on long stalks. Rare. Along the Platte near Valverde. Summer.

302. Verónica Americána L. Stems spreading diffusely on the ground, racemes numerous in the axils of the opposite leaves, corolla blue, falling soon; porls swollen, leaves usually 
short petioled, ovate, serrate. Growing in marshy places along the Platte and Cherry Creek, Spring and summer.

303. Verónica peregrina L. Stems erect, flowers in the axils of the leaves on short stalks, pods obcordate. Common along the ditches. Summer.

304. Gerárdia tenuifólia VAHL. Stems simple up to the inflorescence, where it branches into several racemes, corolla rose color, pods round, half covered by the toothed calyx. The form here is var. macrophyilla Benth. Found in marshy places along the Platte and Cherry Creek. Fall.

305. Castilléia íntegra Gray. (Painter's Brush.) Stems erect, usually branching, from near the base, bracts bright scarlet, covering all the flowers except the long beak of the corolla, which extends nearly an inch beyond. On the Valverde and Berkeley hills. Spring to fall.

306. Orthocárpus lúteus Nutr. Erect, simple, leafystemmed, viscid and hispid, corolla yellow with an inflated sac-like lower lip. The leaves and bracts are not colored. Rare, Clear Creek, near Berkeley. Summer.

\section{OROBANCHÁCEÆ. (Broom-Rape Family.)}

307. Aphýllon fasciculatum Gray. Stem white or brownish, flowers tinged with purple, on long peduncles. Parasite on sagebrush, the root is round and fleshy. South Denver. Summer.

308. Aphýllon Ludoviciánum Gray. Spikes densely flowered, often compound or several from the same root. Parasitic on sagebrush or Bigelovia. Less common than the preceding. North Denver, near Argo. Summer.

\section{VERBENÁCE $Æ$. (Verbena Family.)}

309. Verbéna hastáta L. Tall, leafless spikes numerous and clustered at top of the stem, corolla blue. Along the Platte. Summer to fall. 
310. Verbéna strícta Vent. Erect and densely leaved, white hairy all orer, flowers in dense spikes at the top of the stem, but leafy at the base of the clusters. Near Montclair. Summer.

3II. Verbéna bracteósa Michx. Decumbent stems branching from the base, leaves variously cut on the margins, spikes dense, bracts leafy, flowers small, corolla blue. Very common on the plains. Summer to fall.

312. Verbéna Aublétia L. 'This resembles the cultivated Verbena in the shape of the flower clusters and manner of growth, corolla large, dark lilac. Valverde, on the hills. Early summer.

313. Lippia lanceolátá Mrchx. Stems many, long and creeping, leaves narrowed to the stalk, serrate above; flowers in a dense head which becomes spike-like with age. Corolla pink.

\section{LABIÁT Æ. (Mint Family.)}

314. Méntha Canadénsis L. (Mint.) Small lilac flowers, clustered in the axils of the upper leaves. Common along the ditches. Summer.

315. Méntha viridis L. (Spearmint.) Escaped from cultivation. North Denver. summer.

3r6. Lýcopus sinuátus Erl. (Water-horehound.) The few sessile flowers elustered in the axils of the sharply serrate leaves, calyx with five long, awn-like divisions. Along the ditches, etc. Common. Summer.

317. Pycnánthemum lanceolátum Pursh. Reported from near Denver by Dr. Smith.

318. Hedeóma híspida Pursh. Stems simple or branched below into simple branches, flowers clustered all along the stems in the axils of the short linear leaves. Corolla small, blue, as long as the two-lipped bristly calyx. Along the Platte near Valverde. Summer. It grows in dense patches. 
3rg. Sálvia lanceoláta Wirld. From low anıl simplestemmed to tall and branching diffusely, corolla blue, small but exceeding the calyx, which is persistent and becomes brown when dry. Usually flowers and fruit on same plant at the same time. Summer and fall.

320. Monárda fistulósa L. (WILD Bergamo'.) Sweet scented, heads of large purple flowers at the top of the stem with an involucre of green bracts. Along the Platte. Summer.

321. Monárda citriodóra Cerv. (Horse-mint.) Stems many from the root. flowers densely clustered in the upper axils, bracts and calyx teeth having branching bristles that are often purplish, corolla tube as long as the calyx. On the -plains. Summer.

322. Népeta Cataria L. (CATxip.) Introduced along the Platte near Valverde.

323. Dracocéphalum parvifórum Nutr. (Dragon-head.) Tall, branching from the base, flowers in a spike at the top of the stems, bracts numerous, bristle-toothed, calyx two-lipped, upper lip ovate-acuminate, lower 3-cleft, all bristle-tipped; corolla small, lilac, almost concealed by the calyx and bracts. Along the Platte. Summer.

324 Scutellária resinósa Torr. (SkUldcap.) This has slender running root stalks and many low stems, flowers in the axils of the upper leaves, but sometimes blooming from the base of the stem, large, deep blue, calyx large, inflated, whole plant resinous. Common on the plains of North Denver on the sandy hills. Spring and early summer.

325. Scutellária galericuláta L. 'Taller, usually branching above, leaves more seattered. This grows in wet places along the Platte. Summer.

326. Brunélla vulgáris L. (SELF-HEAL.) Branching from the root, the pairs of leaves distant, flowers in a spike at the 
top of the stem, bracts very broad and rounding, ciliate and veiny, corolla bright purple. Along the Platte. Summer.

327. Stáchys palústris L. (Woundwort.) Stem tall and erect, rough, hairy spike at the top of stem, interrupted, corolla pink. 'This is without an aromatic odor. Common in damp places. Summer.

\section{PLANTAGINÁCEÆ. (Plantain Family.)}

328. Plantágo májor L. The common plantain with broad veiny leaves. Common. Summer and fall.

329. Plantágo Patagónica JACQ var. gnaphalióides GRAY. This is the low, white, woolly plantain of the prairies; the flowers are in dense and numerous spikes, corolla is white and papery. Common in the spring, often covering the ground for. acres with a silvery foliage.

330. Plantago lanceolata L. Introduced. Not common. NYCTAGINÁCEAE. (Four-o'clock Family.)

331. Oxýbaphus nyctagineus SweEt. This has purple flowers and heart-shaped leaves. The stem is tall and branched. Along the Platte and Cherry Creek in the shade. Summer. The var. oblongifolius is found along the ditches in the open country.

332. Oxýbaphus angustifólius SwEET. This has long linear leaves, calyx delicate and white, involucre papery, fruit hoary. Common on the plains in late summer. These open in the evening. The var. oblongifólius also grows at Denver along the ditches.

333. Abrónia frágrans Nutt. (Fragrant Abronia.) Stems thick and fleshy, many from the root, spreading along the ground; umbels axillary on the long peduncles, head of fruit globular, flowers white and with a strong sweet perfume, which causes it to be wrongly named wild heliotrope. Common in sandy places. Summer. 
334. Abronia micrantha Torr. Wings of fruit fleshy, pink veined, forming a round head, flowers small. Not common. Summer.

\section{AMARANTÁCEæE. (Amaranth Family.)}

335. Amarántus retrofléxus L. (PIG-weed.) Tall and stout, spikes at tips of branches thick and erect, bracts awned. A common weed. Fall.

336. Amarántus álbus L. Rather low, diffusely branching, leaves and bracts awned, clusters of flowers small and axillary; seed wrinkled, black or dark red and shiny. Common in the fall.

337. Amarántus blitóides Watson. Prostrate, leaves obtuse with a very short awn, clusters of flowers axillary; seed shining, black, not wrinkled, larger than the preceding. Common in the fall.

338. Amarántus Tórreyi Bexth. Spreading from the base with long branching ascending stems, often diøcious, the spikes at the ends of the branches very long and slender, often gracefully curved. In sandy ground. North Denver and Capitol Hill near Eighth Avenue. Fall.

339. Acnída tuberculáta Moq. North Denver. Fall.

340. Frœlíchia grácilis MoQ. White-woolly, leaves clustered near root, erests on the calyx stiff.

341. Frœlíchia Floridána MoQ. Stem leafless above, teeth on the calyx irregular.

\section{CHENOPODIÁCEAE. (Goosefoot Family.)}

342. Cycloclóma platyphýllum Moq. The diffusely branching purple or green tumble weed. North Denver. Fall.

343. Chenopódium álbum. (Lamb's-Quarter.) Cómmon. Introduced probably. 
344 Chenopódium hýbridum L. Near Denver, rejorted by Dr. Smith.

345. Chenopódium gláucum L. Rather common. Fall.

346. Chenopódium cornútum BeNth. \& Hook. Aromatic glandular, flowers small and very much crowder in long spikes at the ends of the stems. Along the Platte near Valverde. Summer and fall.

347. Chenopódium capitátum Watson. (SQUaw-Paint.) Clusters of fruit red and fleshy. Reported by Dr. Smith and B. H. Smith.

348. Chenopódium úrbicum L. On Euclid Street above Goss Street in North Deuver.

349. Monolépis chenopodióides Moq. Rather common.

350. Átriplex pátulum L. var. hastátum Gray. Common in North Denver. Fall.

351. Átriplex argénteum Nutr. North Denver. Summer.

352. Átriplex canéscens James. A shrub, Berkeley. Summer and fall.

353. Átriplex róseum L. Introduced in North Denver near where the Sixteenth Street cable turns. Fall.

354. Súckleya petioláris Gray. Found near Denver by Thomas Meehan.

355. Eurótia lanáta Moq. (White-Sage, Wixter-Fat.) Valverde Hills near Riverside cemetery. Summer. Fall.

356. Corispérmum hyssopifólium $L$. Common in North Denver and near Arlington Park. Fall.

357. Suǽda depréssa Watsox var. erécta Watson. Stems from a woody base, leaves rounả, fleshy, and crowded. North Denver. Fall.

358 Sálsola Káli L. Introduced along the railroad tracks. Summer and fall. 


\section{POLYGONÁCEEE. (Buckwheat Family.)}

359. Eriógonum heracleóides Nutr. Clusters in compound umbels with the rays often branched, flowers yellow, smooth. Clear Creek, found by Miss E. Eaton. Summer.

360. Eriógonum ánnuum NuTr. Entire plant white, tall, sometimes branching but usually simple to the cymose clusters. Common on the plains. Summer.

361. Eriogonum cérnuum Nutr. Diffusely branching, clusters numerous on deflexed pedicels, flowers white, becoming pink. Near Valverde on the Denver and Rio Grande railroad track. Summer.

362. Eriógonum microthécum NutT. var. effúsum TorR. \& Gray. Low, branching from a woody base, cyme of small clusters very much branched. Common on the plains. Fall.

363. Rúmex venósus Pursh. Easily distinguished by the large rose colored veiny valves and the thickly clustered flowers. Near Cherry Creek, North Denver. Early summer.

364. Rúmex salicifólius Weirmaxn. The common narrow leaved Rumex. Common. Summer to fall.

365. Rúmex Acetosella L. The common sorrel. Introduced. Not common.

366. Polygonum eréctum L. Branches leafy to the summit.

367. Polýgonum ramossissimum Mrchx. Branching above, yellowish, upper leaves bract-like.

368. Polýgonum ténue Michx. Slender and rather low, spikes distantly flowered. In wet places. Valverde. Fall.

369. Polýgonum aviculáre L. (Кхот-Grass) The very common introduced prostrate Polygonum.

37o. Polýgonum Pennsylvánicum L. Stems very tall, five or six feet and leafy, upper part covered with glandular 
bristles; flowers in a close spike, rose color. Valverde, in a swampy place where the vegetation was all tall.

371. Polýgonum amphibium L. Aquatic, with floating leaves and spikes of rose-colored flowers. In a pond between Denver and Morrison. Summer.

372. Polýgonum Muhlenbérgii Watson. In muddy places with creeping stems. Similar to the preceding. Along the Platte. Summer.

373. Polýgonum Hartwríghtii Gray. (SMART-weed.) Branched from the base, slender stems often rooting at the joints. Spikes of rose-colored flowers, numerous. Common along the ditches, etc.

374. Polýgonum Hydropiper L. Small, few-flowered spikes terminating the slender stems, flowers white. Along the Platte. Common in marshy spots. Fall.

375. Polýgonum dumetórum L. var. scandens GRAY. Similar in appearance to the morning-glory vine. Common.

\section{SANTALÁCEÆE. (Sandal-wood Family.)}

376. Comándra pállida DC. Stems many from a woody root, glaucous, terminated by umbels of creamy flowers, petals rather thick and sometimes tinged with pink. Common on the plains and along the Platte. Spring.

\section{EUPHORBIÁCEÆ. (Spurge Family.)}

377. Euphórbia petalóidea Evgelm. Prostrate, leaves entire with fringe-like stipules. Common. Seeds reddish. Summer and fall.

378. Euphórbia glyptospérma ExGelm. Near Denver, Dr. Smith.

379. Euphórbia maculáta L. Prostrate, leaves serrate, seeds 4-angled and each side grooved, the whole plant becoming red. Common. Summer and fall. 
380. Euphorbia hexagona NUtT. Found by T. C. Porter near Denver.

381. Euphórbia margináta Pursh. (SNow-on-the-Mountain, Margined-Spurge). Leaves usually white margined, markings variable. Common on the plains. Summer to fall.

382. Euphórbia dentáta Michx. Tall and erect, leaves often blotched with purplish red: Common in the late summer and fall.

383. Euphórbia dictyospérma Fisch. ANd Meyer. Annual, pod warty, seeds veined. Along the Platte. Summer.

384. Euphórbia montána Evgely. Pod smooth, seeds dotted, very leafy. Common along the Platte.

\section{CALLITRICHÁCEȦ.}

385. Callitriche vérna L. In stagnant water, near Valverde.

\section{URTICÁCEÆ. (Nettle Family.)}

386. Úrtica grácilis Ait. (NetTle.) Along streams, not very common.

387. Húmulus Lúpulus L. (Hop-vive.) Along the Platte. Common.

\section{CUPULIFERÆ. (Oak Family.)}

388. Bétula occidentális Ноok. Along the Platte near Denver. Coulter.

389. Álnus viridis AIt. Along the Platte near Valverde.

SALICINEAE. (Willow Family.)

39o. Sálix amygdalóides Anders. Leaves narrowed to a very fine point, glaucous beneath, serrate, catkins on leafy peduncles. Along the Platte. North Denver. Common. 
391. Sálix longifolia Muнr. Leaves narrow, lanceolate, sparingly short, bristly-toothed, canescent with fine close hairs especially on the young shoots. Common along the streams, latest in bloom.

392. Sálix cordáta MuHL. Near Denver. Coulter.

393. Sálix irroráta Anders. Leaves with yellow midrib and very glaucous beneath. I have not the flowers or fruit of this. Along the Platte near Valverde bridge.

\section{angulata, ait.}

394. Pópulus balsamiferaquvar. eandieans-GAYr. The common broad-leaved cottonwood. Along the Platte and the ditches.

395. Pópulus angustifólia JAMEs. The narrow or willowleaved cottonwood. Along the Platte and the ditches.

\section{IRIDÁCEÆ. (Iris Family.)}

396. Íris Missouriénsis NutT. (Blue-FlaG.) In a meadow near Baker's Pond near the Larimer Street viaduct. Spring.

397. Sisyrínchium mucronátum Michx.

(BLUE-EYED Grass.) Along the Platte. Surmmer. Not common.

\section{LILIACEA. (Lily Family.)}

398. Állium reticulátum Fraser. The wild onion with umbels of white flowers. North Denver. Spring.

399. Leucócrinum montánum Nutt. (White PrairieLILy.) One of the earliest flowers, with long, grass-like leaves and delicate white fragrant lilies from an erect root stalk. Common on the plains. Spring. The seeds ripen under the ground.

400. Smilacína stelláta Desf. (FAlse Solomon's-Seal.) Leaves numerous and clasping, small delicate white flowers in a short, terminal raceme. Berries at first striped with red, when fully ripe red all over. In shady spots along the Platte and Cherry Creek. 
40r. Yúcca angustifólia Pursh. (Soap-Weed. SpanishBAYONET.) With bayonet-shaped leaves and a raceme of drooping flowers which are thick and large, cream color and usually tinged with pink. Common on the plains. Summer.

402. Calochórtus Gunnisóni Watson. (Mariposa Lily.) This was found near Clear Creek, about six miles from the city by Albert Eaton. He reports it as very abundant.

403. Zygadénus Nuttállii Gray. Bulb like an onion, buried deep, stem with leaves crowded near the base, few-leaved above. Raceme densely flowered on the long scape. On the plains. Rather common. Spring.

\section{COMMELYNÁCEAE. (Spiderwort Family.)}

- 404. Tradescántia Virgínica L. (SPIDerwort.) Stems leafy, flowers deep blue in a sessile umbel. Common. Spring and early summer.

\section{JUNCÁCEÆ. (Rush Family.)}

405. Lúzula spicáta Desf. Dr. Smith.

406. Júncus Bálticus Deth. var. montánus Exgelm. Common.

407. Júncus bufónius L. Common along Cherry Creek and the Platte.

408 Júncus longistýlis Torr. Dr. Smith and B. H. Smith.

409. Júncus nodósus L. var. megacéphalus TorR. Dr. Smith and B. H. Smith.

\section{TYPHÁCEÆ. (Cat-Tail Family.)}

4ro. Týpha latifólia L. (CAT-'TAIL.) Common in the ponds and marshes.

4II. Spargánium eurycárpum Evgelm. (BUR-Reed.) Stems tall and stout; clusters of fruit globular, lower on stalks, upper sessile. In a marsh near Valverde. Summer. 


\section{LEMNÁCEAE. (Duckweed Family.)}

412. Lemna minor L. (Deck WeEd.) A tiny twō-leaved plant that floats on the water, often making the surface of small ponds green. Along the Platte.

\section{ALISMÁCEÆ. (Water-Plantain Family)}

4I3. Alísma Plantágo $\mathrm{L}$. Leaves on long stalks, plantain like; umbels of flowers whorled, either simple or compound; flowers white, small. ('ommon along the Platte. Summer and fall.

414. Sagittária variábilis EvgeLM. Leaves arrow-shaped; flowers delicate, white. Common in the marshes. Summer.

NAIADÁCE

4I5. Potamogéton nátans L. In ponds, etc. Not common. Summer to fall. It grows in a small pond near Argo ancl in several places along the Platte.

\section{CYPERÁCEAE. (Sedge Family.)}

416. Cypérus aristátus Rơtrb. Along the Platte. Sum11) er.

417. Cypérus infléxus Muht. Dr. Smith.

$4^{18}$. Scírpus púngens YaHL. Dr. Smith.

419. Scirpus lacústris VAHL. Dr. Smith.

420. Elećcharis aciculáris R. BR. Dr. Smith.

421. Eleócharis palústris R. Br. Along the Platte.

422. Eleócharis olivácea Torr. Along the Platte.

423. Cárex stramínea Willd. B. H. Smith. There are many more of the genus Carex, but they have not been collected.

\section{GRAMÍNEE. (Grass Family.)}

424. Beckmánnia erucæfórmis Host. Along streams.

425. Pánicum capilláre L. (OLD-Witch GRass.) Introduced. 
426. Pánicum virgátum L. Common.

427. Pánicum Crus-galli L. (Barnyard Grass.) Introduced.

428. Pánicum sanguinale L. (Crab or Finger-Grass.) Introduced.

429. Pánicum scopárium Lav. Common.

430. Setaria víridis Beauv. (FoxtaIL.) Introduced.

43r. Setária glaúca Beauv. (Green-FoxtaIl.) Introduced.

432. Setária Itálica Kunth. (Millet.) Introduced.

433. Cénchrus tribulóides L. (SAND-Bur.)

434. Spartína cynosuroídes Willd. (Fresh-W Ater CordGraśs.)

435. Andropógon furcátus Muhl. (Beard-Grass.) Perrin's meadow.

436. Andropógon scopárius Michx. Perrin's meadow.

437. Chrysopógon nútans Bexth. (Indian-Grass.) (Woop Grass.)

438. Phálaris Canariénsis L. (CANary-Grass.) Introduced.

439. Alopecúrus geniculátus L. var. aristulátus TokR.

440. Aristida purpúréa NutT. var. longiseta VASEY.

441. Stipa comáta Trin. (Feather-Grass.)

442. Stipa virídula Trin.

443. Oryzópsis cuspidáta Benth. (Quivering-Grass, Mountain-Rice.)

444. Muhlenbérgia sylvática Torr. \& Gray. (Drop-Seed Grass.

445. Phléum praténse L. ('Тммотну.) Introduced. 
446. Sporóbolus airóides Torr. (Rush-Grass, Dropsend Grass̀.)

447. Sporóbolus confúsus VASEY.

448. Sporóbolus asperifólius THURB. duced.

449. Dáctylis glomeráta L. (ORchaRD-Grass.) Intro-

450. Agróstis álba L. (Bent-Grass.)

451. Agróstis exaráta Trin.

452. Agróstis scábra WILLD.

453. Polypógon Monspeliénsis Desf. (Beard-Grass.)

454. Calamagróstis sylvática DC.

455. Calamagróstis longifólia Hook.

456. Deschámpsia cæspitósa BEAUV.

457. Schedonnárdus Texánus STEUd.

458. Bouteloúa hirsúta LAG. (Grama-Grass.)

459: Bouteloúa oligostáchya TorR.

46o. Bouteloúa racemósa LAG.

46r. Búchloe dactyloídes Engelm. (Buffalo-Grass.)

462. Phragmites commúnis Trin. (REed-Grass.)

463. Múnroa squarrósa ToRR.

464. Kœléria cristata Pers.

465. Eatónia obtusáta Gray.

466. Eragróstis Púrshii Schrader.

467. Eragróstis májor Host.

468. Eragróstis pilósá BEAUV.

469. Distichlis marítima RAF.

470. Põa flexuosa MuHL. var. occidentális VASEY. 
47x. Póa brevifólia MuHL.

472. Glycéria acutiflóra ToRR.

473. Glycéria flúitans $R$. BR

474. Glycéria pállida Trin.

475. Glycéria nerváta Trin.

476. Glycéria grándis Watson.

477. Festúca ovina $\mathrm{L}$.

478. Festúca tenélla WILLD.

479. Agropýrum glaúcum R. \& S. var. occidéntale V.\& S. 480. Agropýrum ténerum Vasey.

481. Élymus Canadénsis L.

482. Élymus Virgínicus L. var. submuticus Ноок.

483. Hórdeum jubátum L.

484. Marsilia vestíta Ноок. \& Grev. This was found near Montclair in a swampy place that had become dry.

485. Equisétum arvénse $L$.

486. Equisétum lævigátum BRAUN.

487. Equisétum variegátum ScHLEICHER.

These three species of Equisetum grow along the Platte River and Cherry Creek.

No ferns have been found; only two mosses have been noticed and one liverwort. 


\section{N DEX.}

\begin{tabular}{|c|c|}
\hline & \\
\hline bronia ..........................42, 43 & Brickell:a........................ \\
\hline cerates............................... 32 & Brunella............................ 41 \\
\hline chillea........................... & …................... 52 \\
\hline cnida.......................... & Calamagr stis................ \\
\hline Agropyrum....................... & (allitri hacee..................... 47 \\
\hline Agrostis .......................... & Callitriche........................... 47 \\
\hline Alisma ................................ 50 & Calo hortus....................... 49 \\
\hline Alismacere ............................ 50 & Camelina............................... 5 \\
\hline Allium ................................ 48 & Camp:nula.......................... 31 \\
\hline Alnus ... ............................ 4 & Campanulacere ....................... 30 \\
\hline Alopecurus............................. 5 & Capparidacere........................ \\
\hline Amarantaceæ....................... 43 & Capr foliacexe ......................... 19 \\
\hline Amarantus............................ 43 & Capsella ............................... \\
\hline Ambrosia ........................ & Carex ............................... \\
\hline mania............................. 15 & Caryoplıylla eæ........................ \\
\hline Amorpha.............................. 11 & Ca-tilleia ............................ 39 \\
\hline Ampelopsis............................ & ('enchrus... .......................... 51 \\
\hline Anacardiaceæ....................... 9 & Cerastium ........................... 7 \\
\hline Andropogon ......................... 51 & Cerens............................... \\
\hline Anemone......................... 3 & Chrenactis ........................ \\
\hline Antennaria.......................... 23 & Chenopodiacer....................... \\
\hline hemis...................... & $\operatorname{lium} \ldots \ldots \ldots \ldots \ldots \ldots . \ldots \ldots, 43$ \\
\hline 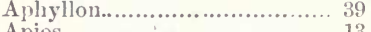 & num $\ldots . . . . . . . . .$. \\
\hline$\ldots \ldots \ldots \ldots \ldots, \cdots$ & (....................... \\
\hline Us. .......................... 20 & $\cdots \cdots \cdots \cdots \cdots \cdots \cdots \cdot$ \\
\hline cer $\ldots \ldots \ldots \ldots \ldots \ldots \ldots \ldots \ldots, 31$ & um $\ldots \ldots \ldots \ldots \ldots \ldots \ldots \ldots \ldots$ \\
\hline 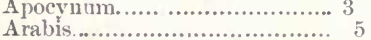 & 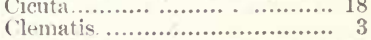 \\
\hline A rgemone ............................ 4 & 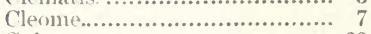 \\
\hline stida ................................ & Cnicus................................... 28 \\
\hline Artemisia.......................... & Comandra ........................... \\
\hline piadaceæ........................ 31 & Commelynaceæ................... \\
\hline Asclepias........................31, 32 & . \\
\hline n....................... & olvulacere................ \\
\hline Astragalus...........................11, & volvulus.. ......................... \\
\hline 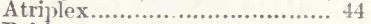 & 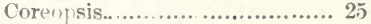 \\
\hline न................... & Corispermum ......................... 4 \\
\hline kmannia...................... & Cornacere.............................. 19 \\
\hline a............................. & C ruus ,.......................... \\
\hline$\because \cdots$ & Corylalis............................... \\
\hline (n) & 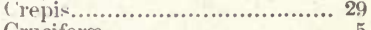 \\
\hline 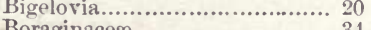 & 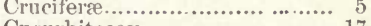 \\
\hline raginaceæ ........................... 3 & Cncurbitaceæ........................ I \\
\hline Brassica ............................... 6 & 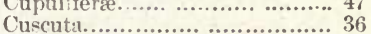 \\
\hline
\end{tabular}


PAGE.

Cyciocloma.............................. 43

Cymopterus............................ 18

Cyperaceæ............................ 50)

Cyperus .............................. 50

Dactylis.............................. 52

Dalea................................. 10

Datura................................... 37

Delphinium. ......................... 4

Deschampsia..................... 52

Distichlis............................. 52

Draba................................. 5

Dracocephalum...................... 41

Dysoklia............................ 26

Eatonia.................................. 52

Echinocystis........................ 17

Echinospermum ..................... 35

Eleocharis............................ 50

Ellisia....................................... 34

Elymus................................ 53

Epilobium........................... 15

Equisetum........................... 53

Eragrostis.............................. 52

Erigeron.................................. 22

Eriogonum ............................ 45

Erodium ................................ 9

Erysimum......................... 5

Euphorbia......................46, 47

Euphorbiaceæ...................... 46

Eurotia ................................. 44

Eustoma................................... 32

Evolvulus............................ 36

Festuca............................. 53

Fragaria............................... 13

Franseria.............................. 23

Froelichia............................ 4:3

Fumariaceæ.......................... 4

Galium............................... 19

Gaura ..................................... 16

Gayophytum. ....................... 15

Gentiana ..............................

Gent a naceæ........................... 32

Geraniaceæ........................... 8

Geranium............................. \&

Gerardia.............................. 39

Geum .............................. 13

Gilia ................................... $3: 3$

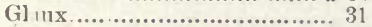

Glyceria ........................... 53

Glyeyrrhizit........................... 11

Gnaphalium........................ 23

Grimineæ ............................. 50

Grindeli:1............................. 20

Gutierrezia .. ........................ 20

Grmnolomia......................... 24

Hedeoma................................... 40

Helenium ............................ 26
PAGE.

Helianthus......................24, 25

Heliotropium......................... 34

Heracleum............................. 18

Hordeum................................ 53

Humulus............................. . 47

Hydrophyllaceæ....................... 34

Hymenatherum.................... 26

Hymenopappus...................... 26

Ipomøa .............................. 36

Iridaceæ............................. 48

Iris................................... 48

Iva....................................... 23

Juncaceæ............................... 49

Juncus.................................. 49

Koleria ................................... 52

Krynitzkia........................... 35

Kuhnï............................. 19

Labiatæ .............................. 40

Lactuca................................ 30

Lathyrus ............................... 13

Leguminosæ......................... 9

Lemna.................................... 50

Lemnacer................................. 50

Lepachys............................... 24

Lepidinn.............................. i

Lesquerella............................ 6

Leucocrinum. ............................ 48

Liatris. .................................. 20

Lili:ıeæ................................ 48

Linaceæ.................................. 8 8

Linum................................. \&

Lippia............................. 40

Lithospermum....................35, 36

Loasaceæ........................... 17

Lobelia................................. 30

Lobeliacere................................ 30

Lonicer. ... ............................ 19

Lnpinus............................... 10

Lnzula ................................ 49

Lychnis............................. 7

Lyсорих.............................. 40

Lygodesnita.......................... 29

Ly: hracex............................... 15

Lythrum .............................. 15

Mialva ................................. 8

Malvacex................................ 8 8

Malvastrum......................... \&

Mamillaria ............................ 17

Marsilia ................................... 53

Medisago.............................. 10

Melilotus ................................ 10

Mentha............................... 40

Mentzelia................................. 17

Mertensia......................... 35

Mimulus............................. 38

Monarda ............................... 41 


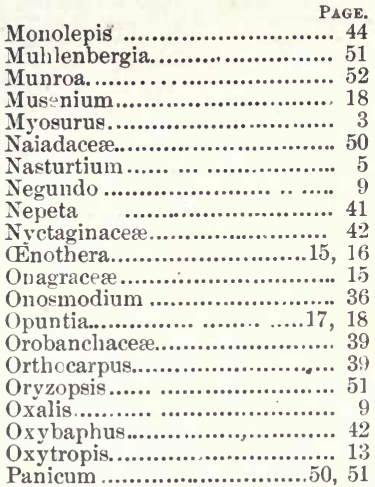

Papaveraceæ.......................... 4

Pastinaca............................. 18

Pentstemon............................... 38

Petalostemon......................... 11

Peucedanum.......................... 8

Phacelia................................ 34

Phalaris................................ 51

Phleum ............................... 51

Phlox................................... 32

Phragmites ........................... 52

Physalis ............................. 37

Physaria............................... 6

Plantaginaceæ......4................ 42

Plantago.............................. 42

Poa...................................52, 53

Polanisia ............................. 7

Polemoniaceæ. ....................... 32

Polemonium.......................... 34

Polygonaceæ........................ 45

Polygonum .......................45, 46

Polypogon.............................. 52

Populus ................................ 48

Portulaca............................... 8

Portulacaceæ........................... 8

Potamogeton. ......................... 50

Potentilla .............................13, 14

Primulaceæ.......................... 31

Prunus................................... 13

Psoralea.................................. 10

Pycnanthemum.................... 40

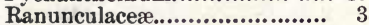

Ranunculus ............................. 4,4

Raphanus.............................. 6

Rhus................................... 9

Ribes.................................... 15
PAGE.

Rosa ............................... 14

Rosaceæ............................... 13

Rubus..................................... 13

Rudbeckia............................ 24

Rumex.................................. 45

Sagittaria............................. 50

Salicineæ............................. 47

Salix................................47, 48

Salsola .................................. 44

Salvia................................. 41

Santalaceæ.............................. 46

Sapindaceæ........................... 9

Saponaria.......................... 8

Saxifraga............................. 14

Saxifrugaceæ............................ 14

Schedonnardus........................ 52

Scirpus................................. 50

Scrophularia......................... 37

Scrophulariaceæ .................... 37

Scutellaria............................. 41

Senecio.................................. 28

Setaria ................................. 51

Sidalcea ............................... 8

Silene .................................... 7

Sisymbrium.......................... 6

Sisyrinchium ......................... 48

Smilacena ............................. 48

solanaceæ ................................ 37

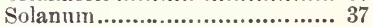

Solidago..............................20, 21

Sonchus ............................... 30

Sophora............................. 10

Sparganium............................ 49

Spartina................................ 51

Specularia ............................ ${ }^{-30}$

Sporobolus............................ $: 2$

Stachys............................... 42

Steironena ............................. 31

Stephanomeria...................... 28

Stipa................................... 51

Sureda................................... 44

Suckleya.................................. 44

Symphoricarpos..................... 19

Talinum................................ 8

Taraxacum ............................... 29

Thalictrum........................... 3

Thelesperma........................... 25

Thermopsis............................ 9

Townsendia .......................... 21

Tradescantia............................. 49

Tragopogon........................... 29

Trifolium............................... 10

Troximon ............................... 29

Typha..................................... 49

Typhaceæ.............................. 49

Umbelliferæ......................... 18 


\begin{tabular}{|c|c|}
\hline ica................................ & ..................... \\
\hline Urticaceæ.......................... 47 & Violaceæ... \\
\hline Verbena ............................39, 40 & Vitaceæ ....... \\
\hline Verbenaceæ .......................... 39 & Vitis ........... \\
\hline rbesina ........................... 25 & Xanthium.. \\
\hline onica..........................38, 3 & Yucca........... \\
\hline cia.................................. & Zygadenus........................... 49 \\
\hline
\end{tabular}




\section{ZO E}

A WESTERN BIOLOGICAL JOURNAL.

Published Quarterly by the

ZOE PUBLISHING COMPANY, San Francisco, California.

Subscriptions, \$2.00 Per Year; Single Numbers, 75 Cents

Address

P. O. Box 2114.

\section{ZOE PUBLISHING COMPANY,}

San Francisco, Cal.

\section{Books}

Your reading for the coming year should include a monthly

\section{Book Reviewer.}

\section{That's what BOOKS is.'}

It contains good things from

\section{Current Thought, Opinion, Literature.}

SEND FOR SAMPLE COPY.

R. L. HARPER, BUSINESS MANAGER, 

mar $10 / 23$

$$
\text { fordge }
$$





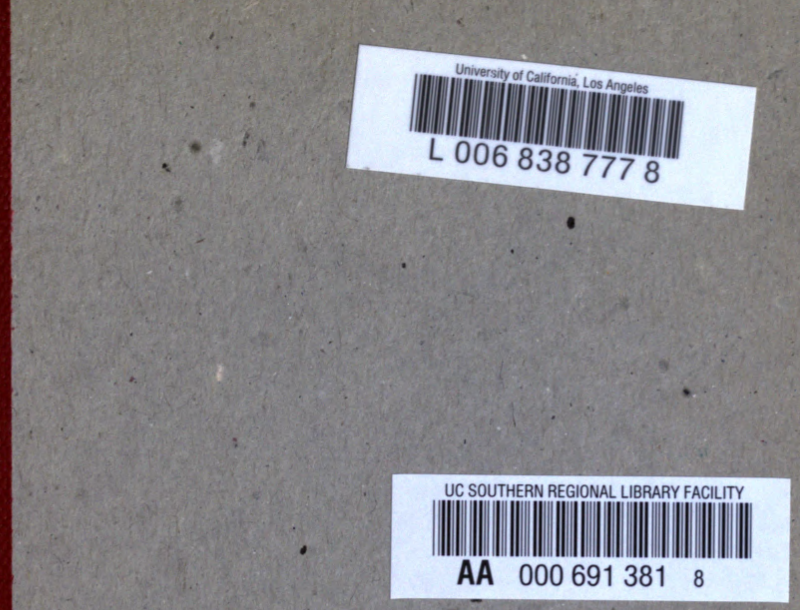


